\title{
Study of antioxidant activities of extracts from Metaplexis japonica leaf and stem
}

\author{
Ju-Yeon Hong, Seung-Ryeul Shin* \\ Faculty of Herbal Food Cuisine and Nutrition, Daegu Haany University, Gyeongsan 38610, Korea
}

\section{박주가리(Metaplexis japonica Makino) 잎과 줄기 추출물의 항산화 효과에 관한 연구}

\author{
홍주연·신승렬* \\ 대구한의대학교 한방식품조리영양학부
}

\begin{abstract}
The purpose of this study was to evaluate the antioxidant activity of Metaplexis japonica by using hot-water and ethanol extracts of its leaf and stem. Yields of hot-water and ethanol extracts of $M$. japonica leaf were high at 6.89 and $6.23 \%$, respectively. The polyphenol and flavonoid contents in ethanol extracts of $M$. japonica leaf (ALEE) were high $(86.96$ and $60.73 \mathrm{mg} / \mathrm{g}$, respectively). The electron-donating ability of all $M$. japonica extracts increased with an increase in extract concentration, with the highest electron-donating ability of $36.20 \sim 68.19 \%$ shown by hot-water extracts of M. japonica leaf (ALWE). The superoxide dismutase (SOD)-like activities of ALWE and ALEE increased with an increase in extract concentration. The nitrite-scavenging ability of the extracts was the highest at $\mathrm{pH} 1.2$ and that of ALWE was higher than that of ALEE. The reducing power of $62.5 \mathrm{\mu g} / \mathrm{mL}$ ALEE was 0.09 and that of $1,000 \mathrm{\mu g} / \mathrm{mL}$ ALWE was 0.44 . The inhibitory effect of an ethanol extract of $M$. japonica stem (ASEE) on tyrosinase was $13.81 \%$ at a concentration of $62.5 \mu \mathrm{g} / \mathrm{mL}$ and that of $1,000 \mu \mathrm{g} / \mathrm{mL}$ ALEE was $57.04 \%$.
\end{abstract}

Key words : Metaplexis japonica, leaf, stem, anti-oxidant, functionality

\section{서 론}

현대인들은 생활환경과 식생활 패턴의 변화 등으로 과도 한 스트레스가 유발됨으로 인하여 암, 심장질환, 동맥경화, 고혈압 등과 같은 각종 성인병이 증가하고 있다. 이러한 질병의 원인으로 superoxide anion $\operatorname{radical}\left(\mathrm{O}_{2}\right)$, hydroxyl radical $(\mathrm{OH})$, singlet oxygen $\left({ }^{1} \mathrm{O}_{2}\right)$ 및 hydrogen peroxide $\left(\mathrm{H}_{2} \mathrm{O}_{2}\right)$ 등과 같은 활성산소를 주목하고 있으며, 이러한 활성산소 의 반응성을 감소 또는 무력화 할 수 있는 물질의 발굴과

*Corresponding author. E-mail : shinsr@dhu.ac.kr Phone : 82-53-819-1428, Fax : 82-53-819-1494

Received 3 November 2015; Revised 18 November 2015; Accepted 25 November 2015.

Copyright (c) The Korean Society of Food Preservation. All rights reserved.
이용에 관한 연구가 활발히 이루어지고 있다 $(1,2)$. 식 · 약용 식물들 대부분 부식재료나 구황작물로써 유용하게 이용되 었으며, 특유의 맛과 향, 약효, 계절감 등 다양한 이유로 지금까지도 널리 애용되고 있다(3). 특히 최근에는 건강에 대한 관심이 증가하면서 생체의 리듬조절, 질병치료 및 노 화억제 등 생리활동에 영향을 미치는 여러 가지 건강식품이 나 자연식품에 식 · 약용식물들의 수요가 증가하고 있다 $(4,5)$.

인체의 산화촉진물질(proxidant)과 산화억제물질(antioxidant) 이 균형을 이루고 있으나 여러 가지 요인들에 의하여 이런 균형상태가 불균형을 이루게 되고 산화촉진 쪽으로 기울게 되면, 산화적 스트레스(oxidative stress)가 유발되어 잠재적 인 세포손상 및 병리적 질환을 일으키게 된다(6,7). 이러한 산화적 스트레스의 직접적 원인이 되는 활성산소종 (reactive oxygen species, ROS)은 불안정하고 반응성이 높 
아 여러 생체물질과 쉽게 반응하고 체내고분자들을 공격하 여 세포와 조직에 비가역적인 손상을 일으키거나 돌연변 이, 세포독성 및 발암 등을 초래하게 된다(8,9). 현재까지 항산화제로 이용되고 있는 것들 중에서는 BHA와 BHT와 같은 합성 항산화제는 독성이 문제가 되고 있고 $(10,11), a$ -tocophenol 이나 ascorbic acid 와 같은 천연항산화 물질에 대한 관심이 높으며(12,13), 이들과 유사한 활성을 가진 천 연 물질과 소재의 개발 등에 대한 연구가 활발하게 진행되 고 있다(14-19). 활성 산소를 소거하기 위한 항산화성 물질 을 안전성 문제 때문에 식품이나 천연물에서 찾고자 하는 노력이 많이 시도되고 있다(20,21).

박주가리(Metaplexis japonica Makino)는 박주가리과 (Asclepiadaceae)에 속하는 덩굴성 여러해살이풀로 우리나 라 전국의 들에 흔히 자라며, 일본, 만주, 중국에 분포한다. 예로부터 전초 또는 뿌리 말린 것을 나마(維)라고 하여 보기 (補氣), 생유(生乳), 해독의 효능이 있고 허손노상(虛損勞傷), 양위(陽), 대하, 유즙불통, 단독, 창종을 치료한다고 알려져 왔다. 열매는 나마자(蘿子)라고 하며, 정기(精氣)를 보하고, 생기(生肌), 지혈의 효능이 있고, 허로, 양위, 금창출혈을 치료하는 것으로 알려져 있다(22). 박주가리는 줄기가 주변 의 물체를 감아 올라가는 덩굴성 식물로 덩굴은 방향성이 있고, 박주가리 꽃색은 연한 자주색을 띠며, 꽃모양은 꽃잎 이 5갈래로 갈라지는 특징을 가지고 있다(23).

따라서 본 연구에서는 새로운 기능성 소재의 개발에 우 선하여 박주가리의 부위별인 잎과 줄기의 열수 및 에탄올의 추출방법에 따라 추출물을 제조한 후 각 추출물에 대한 폴리페놀과 플라보노이드 함량, 전자공여능, $\mathrm{SOD}$ 유사활 성, 아질산염 소거능, 환원력, tyrosinase 저해활성을 측정함 으로써 천연 항산화제 개발에 필요한 기초자료를 얻고자 하였다.

\section{재료 및 방법}

\section{재 료}

본 연구의 주재료인 박주가리(Metaplexis japonica Makino) 는 2012년 9월에 경북 경산시 유곡동 일대에서 직접 채취하 였으며, 채취한 박주가리는 이물질을 제거 및 세척한 후 일정량으로 분취하여 초저온냉동기(MDF-U52V, Sanyo, Osaka, Japan)에서 보관하면서 시료로 사용하였다.

\section{추출물의 제조}

박주가리 열수 추출물은 각 시료 10 배에 해당하는 3 차 증류수를 각각 가한 후 $85^{\circ} \mathrm{C}$ 에서 3 시간 동안 환류 추출하였 고 이 과정을 3회 반복 추출하여 모아진 각각의 추출액은 여과지(Whatman No. 2)로 여과하여 제조하였다. 에탄올 추출물은 각 시료에 10 배의 $70 \%$ 에탄올을 가한 후 $50^{\circ} \mathrm{C}$ 에
서 3 시간 동안 환류 추출하였다. 이 과정을 3 회 반복 추출하 여 모아진 추출액을 여과지(Whatman No. 2)로 여과하여 제조하였다. 각 추출액은 회전식감압증발 농축기(R-210, BUCHI, Japan)를 사용하여 감압농축 하였고, 동결건조기 (FD8512, Ilshin, Korea)로 $-90^{\circ} \mathrm{C}$ 에서 동결 건조한 후 플라스 틱용기에 담아서 초저온냉동기(MDF-U52V, Sanyo, Osaka, Japan)에 보관하면서 추출물을 이용한 기능성 실험을 위한 시료로 사용하였다. 그리고 시료의 추출 수율은 추출 전 시료 중량에 대한 추출물의 동결건조 후의 중량 백분율로 나타내었다.

\section{총 폴리페놀 정량}

폴리페놀 화합물의 함량은 Folin-Denis법(24)으로 측정 하였다. 즉, 박주가리 추출물을 $10 \mathrm{mg} / \mathrm{mL}$ 의 농도로 증류수 에 녹인 다음 $0.2 \mathrm{~mL}$ 를 시험관에 취하고 증류수를 가하여 $2 \mathrm{~mL}$ 로 만든 후 여기에 $0.2 \mathrm{~mL}$ Folin-Ciocalteu's phenol reagent를 첨가하여 잘 혼합한 후 3 분간 실온에 방치하였다. 정확히 3분 후 $\mathrm{Na}_{2} \mathrm{CO}_{3}$ 포화용액 $0.4 \mathrm{~mL}$ 를 가하여 혼합하고 증류수를 첨가하여 $4 \mathrm{~mL}$ 로 만든 후 실온에서 1시간 방치하 여 흡수분광광도계(UV-2001, Hitachi, Tokyo, Japan)를 이 용하여 $725 \mathrm{~nm}$ 에서 흡광도를 측정하였다. 이때 총 폴리페 놀 화합물은 tannic acid(Sigma Chemical Co., USA)를 이용 하여 작성한 표준곡선으로부터 산출하였다.

\section{총 플라보노이드 정량}

플라보노이드 함량은 Moreno 등(25)이 행한 방법에 따라 박주가리 추출물을 $10 \mathrm{mg} / \mathrm{mL}$ 농도로 증류수에 녹인 시료 용액 $0.1 \mathrm{~mL}$ 를 취하여 $10 \%$ aluminum nitrate와 $1 \mathrm{M}$ potassium acetate를 함유하는 $80 \%$ ethanol $4.3 \mathrm{~mL}$ 에 혼합하 여 실온에서 40 분간 정치 한 후 흡수분광광도계(UV-2001, Hitachi)를 이용하여 $415 \mathrm{~nm}$ 에서 흡광도를 측정하였다. 총 플라보노이드 정량은 quercetin(Sigma Chemical Co., MO, USA)을 이용하여 작성한 표준곡선으로부터 산출하였다.

\section{전자공여능 측정}

전자공여능은 Blois 등(26)의 방법에 준하여 각 시료의 1,1-diphenyl-2-picryl hydrazyl(DPPH)에 대한 전자공여 효 과로써 시료의 환원력을 측정하였다. 즉 박주가리 각 추출 물을 농도별로 제조한 시료 $2 \mathrm{~mL}$ 에 $0.2 \mathrm{mM} \mathrm{DPPH}$ 용액 $1 \mathrm{~mL}$ 를 가하고, 10 초간 vortex mixing 후 $37^{\circ} \mathrm{C}$ 에서 30 분간 반응시킨 다음 이 반응액을 흡수분광광도계(UV-2001, Hitachi)를 사용해서 $517 \mathrm{~nm}$ 에서 흡광도를 측정하였다. 대 조구는 천연 항산화제인 L-ascorbic acid를 사용하였고, 아 래와 같이 시료첨가구와 무첨가구의 흡광도의 차이를 백분 율 $(\%)$ 로 표시하여 전자공여능으로 나타내었다. 
Electron donating ability $(\%)=[1-(\mathrm{S}-\mathrm{B}) / \mathrm{C}] \times 100$

S : Sample 첨가구의 흡광도

$\mathrm{B}$ : Blank의 흡광도

C : Control(시료 무첨가구)의 흡광도

\section{SOD 유사활성 측정}

SOD 유사활성 측정은 Marklund 등(27)의 방법에 따라 박주가리 각 추출물 $0.2 \mathrm{~mL}$ 에 $\mathrm{pH} 8.5$ 로 보정한 tris- $\mathrm{HCl}$ buffer $(50 \mathrm{mM}$ tris[hydroxymethyl] amino-methane $+10 \mathrm{mM}$ EDTA) $3 \mathrm{~mL}$ 와 $7.2 \mathrm{mM}$ pyrogallol $0.2 \mathrm{~mL}$ 를 가하였다. 그런 다음 $25^{\circ} \mathrm{C}$ 에서 10 분간 반응시킨 후 $1 \mathrm{~N} \mathrm{HCl} 0.1 \mathrm{~mL}$ 로 반응 을 정지시키고 $420 \mathrm{~nm}$ 에서 흡광도를 측정하였다. SOD 유 사활성은 시료 첨가구와 무첨가구 사이의 흡광도 감소율로 산출하였다. SOD 유사활성은 시료 첨가구와 시료 무첨가 구 사이의 흡광도의 감소율로 아래와 같이 환산하였으며, 대조구로는 L-ascorbic acid를 사용하였다.

SOD like activity $(\%)=[1-(\mathrm{S}-\mathrm{B}) / \mathrm{C}] \times 100$

$\mathrm{S}$ : Sample의 흡광도

$\mathrm{B}$ : Blank의 흡광도

C : Control(시료 무첨가구)의 흡광도

\section{아질산염 소거능 측정}

아질산염 소거능은 Kato 등(28)의 방법에 따라 다음과 같이 측정하였다. 즉 $1 \mathrm{mM}$ 의 $\mathrm{NaNO}_{2}$ 용액 $2 \mathrm{~mL}$ 에 각 농도의 시료 $1 \mathrm{~mL}$ 를 첨가하고, 여기에 $0.1 \mathrm{~N} \mathrm{HCl}(\mathrm{pH} 1.2)$ 과 0.1 $\mathrm{M}$ 구연산 완충용액을 사용하여 반응용액의 $\mathrm{pH}$ 를 1.2 로 조정한 후 반응용액의 부피를 $10 \mathrm{~mL}$ 로 하였다. 그리고 37 ${ }^{\circ} \mathrm{C}$ 에서 1 시간 동안 반응시켜 얻은 반응액을 $1 \mathrm{~mL}$ 씩 취하고 여기에 2\% acetic acid $5 \mathrm{~mL}$ 를 첨가한 다음 Griess reagent $0.4 \mathrm{~mL}$ 를 가하여 혼합시켰다. 그런 다음 실온에서 15 분간 방치시킨 후 흡수분광광도계(UV-2001, Hitachi)를 사용하 여 $520 \mathrm{~nm}$ 에서 흡광도를 측정하여 잔존하는 아질산염의 백분율 (\%)로 나타내었다. $\mathrm{pH} 1.2,3.0$ 에서 추출물의 농도 에 따른 아질산염 분해 작용은 $1 \mathrm{mM}$ 의 $\mathrm{NaNO}_{2}$ 용액 $1 \mathrm{~mL}$ 에 각 농도의 각 추출물을 첨가하고 여기에 $0.1 \mathrm{~N} \mathrm{HCl}$ 을 사용 하여 반응용액의 $\mathrm{pH}$ 를 $1.2,3.0$ 으로 조정한 후 반응용액의 부피를 $10 \mathrm{~mL}$ 로 하여 측정하였다. 무첨가구 L-ascorbic acid 를 추출물의 농도와 동일하게 조제하여 사용하였고, 공시 험은 Griess reagent 대신 증류수 $0.4 \mathrm{~mL}$ 를 가하여 같은 방법으로 행하였다.

Nitrite scavenging ability $(\%)=[1-(\mathrm{S}-\mathrm{B}) / \mathrm{C}] \times 100$

$\mathrm{S}$ : Sample의 흡광도

$\mathrm{B}$ : Blank의 흡광도

C : Control(시료 무첨가구)의 흡광도

\section{Xanthine oxidase 저해효과 측정}

Xanthine oxidase 저해효과는 Stripe와 Corte(29)의 방법 에 따라 측정하였다. 즉, 각 시료용액 $0.1 \mathrm{~mL}$ 와 $0.1 \mathrm{M}$ potassium phosphate buffer(pH 7.5) $0.6 \mathrm{~mL}$ 에 xanthine(2 $\mathrm{mM})$ 을 녹인 기질액 $0.2 \mathrm{~mL}$ 를 첨가하고 xanthine oxidase $(0.2 \mathrm{unit} / \mathrm{mL}) 0.1 \mathrm{~mL}$ 를 가하여 $37^{\circ} \mathrm{C}$ 에서 5 분간 반응시킨 후 $1 \mathrm{~N} \mathrm{HCl} 1 \mathrm{~mL}$ 를 가하여 반응을 종결하였다. 그리고 반응액에 생성된 uric acid의 양을 흡수분광광도계(UV-2001, Hitachi) $292 \mathrm{~nm}$ 에서 흡광도를 측정하였다. Xanthine oxidase 저해 효과는 시료용액의 첨가군과 무첨가군의 흡광 도 감소율로 나타내었다. Xanthine oxidase 저해효과는 시료 첨가구와 시료 무첨가구 사이의 흡광도의 감소율로 아래와 같이 환산하였으며, 대조구로는 천연 항산화제인 L-ascorbic acid를 사용하였다.

Xanthine oxidase inhibition(\%) $=[1-(\mathrm{S}-\mathrm{B}) / \mathrm{C}] \times 100$

$\mathrm{S}$ : Sample의 uric acid 생성량

B : Blank의 흡광도

C : Control(시료 무첨가구)의 uric acid 생성량

\section{Tyrosinase 저해효과 측정}

Tyrosinase 저해효과 측정은 Yagi 등(30)의 방법에 따라 행하였다. 반응구는 $0.175 \mathrm{M}$ sodium phosphate buffer (pH6.8) $0.5 \mathrm{~mL}$ 에 혼합액에 mushroom tyrosinase(110 unit $/ \mathrm{mL}) 0.2 \mathrm{~mL}$ 을 첨가하여 $25^{\circ} \mathrm{C}$ 에서 2 분간 반응시켜 반응 액 중에 생성된 DOPA chrome을 흡수분광광도계(UV-2001, Hitachi)로 $475 \mathrm{~nm}$ 에서 측정하였다. Tyrosinase 저해효과는 시료 첨가구와 시료 무첨가구 사이의 흡광도의 감소율로 아래와 같이 환산하였으며, 대조구 L-ascorbic acid를 사용 하였다.

\footnotetext{
Tyrosinase inhibition $(\%)=[1-(\mathrm{S}-\mathrm{B}) / \mathrm{C}] \times 100$

S : Sample의 흡광도

$\mathrm{B}$ : Blank의 흡광도

C : Control(시료 무첨가구)의 흡광도
}

\section{추출물의 환원력 측정}

추출물의 환원력은 Wong과 Chye(31)의 방법을 일부 변 형하여 측정하였다. 박주가리 각 추출물 $0.5 \mathrm{~mL}$ 에 $0.2 \mathrm{M}$ phosphate buffer(pH 6.6) $1 \mathrm{~mL}$ 와 $1 \%$ potassium ferricyanide $1 \mathrm{~mL}$ 를 넣은 다음 잘 혼합하고 $50^{\circ} \mathrm{C}$ 에서 30 분간 반응시킨 후 실온으로 냉각시켜 $10 \% \mathrm{TCA}$ 용액 $1 \mathrm{~mL}$ 를 넣은 다음 10 분간 방치하였다. 이 중 $0.5 \mathrm{~mL}$ 를 취해 증류수 $1 \mathrm{~mL}$ 와 $0.1 \% \mathrm{FeCl}_{3} 0.5 \mathrm{~mL}$ 를 가한 후 흡수분광광도계(UV-2001, Hitachi)로 $700 \mathrm{~nm}$ 에서 흡광도를 측정하였다. 환원력은 흡 광도의 측정값으로 나타내었으며, 대조구로는 BHT(butyl hydroxy toluene, Sigma Aldrich Co., MO, USA)를 사용하였다. 


\section{통계처리}

$\operatorname{Park}(32)$ 의 방법을 응용하여 모든 실험은 3회 이상 반복 실시하였고, 평균표준편차로 표시하였다. 각 실험결과는 IBM SPSS Statistics(21.0, IBM Corp., Armonk, NY, USA)를 이용하여 일원배치 분산분석 one-way ANOVA(analysis of variance)와 Duncan's multiple range test를 실시하여 $\mathrm{p}<0.05$ 에서 유의성을 검증하고, 분석하였다.

\section{결과 및 고찰}

\section{추출물의 수율과 총 폴리페놀 및 플라보노이드 함량}

박주가리 잎과 줄기의 열수 및 70\% 에탄올추출물의 수 율 및 총 폴리페놀 함량과 플라보노이드 함량을 측정한 결과는 Table 1 과 같다.

Table 1. Yield and the contents of polyphenol and flavonoid in the extracts of Metaplexis japonica Makino from leaf and stem

\begin{tabular}{cccc}
\hline Samples $^{\mathrm{l})}$ & Yield $(\%)$ & Polyphenol $(\mathrm{mg} / \mathrm{g})$ & Flavonoid $(\mathrm{mg} / \mathrm{g})$ \\
\hline ALWE & 6.89 & $66.50 \pm 0.10^{\mathrm{b} 2}$ & $40.25 \pm 0.55^{\mathrm{b}}$ \\
ASWE & 5.21 & $41.87 \pm 0.14^{\mathrm{c}}$ & $15.88 \pm 0.41^{\mathrm{d}}$ \\
ALEE & 6.23 & $86.96 \pm 0.24^{\mathrm{a}}$ & $60.73 \pm 0.16^{\mathrm{a}}$ \\
ASEE & 4.77 & $45.02 \pm 0.14^{\mathrm{c}}$ & $19.38 \pm 0.47^{\mathrm{c}}$ \\
\hline
\end{tabular}

${ }^{1)}$ ALWE, Aneilema japonica leaf water extract; ASWE, Aneilema japonica stem water extract; ALEE, Aneilema japonica leaf ethanol extract; ASEE, Aneilema japonica stem ethanol extract.

${ }^{2)}$ All value are expressed as mean $\pm \mathrm{SD}$ of triplicate Determinations. Different superscripts within the column are significantly different at $p<0.05$ by Duncan's multiple range test.

박주가리 잎과 줄기의 열수 및 에탄올 추출물의 수율 측정 결과 박주가리 잎의 열수 및 에탄올 추출물은 각각 $6.89,6.23 \%$ 으로 박주가리 잎의 열수 추출물이 에탄올 추출 물에 비해 수율이 높았으며, 박주가리 줄기의 열수 및 에탄 올 추출물은 각각 $5.21,4.77 \%$ 로 박주가리 줄기의 열수 추출 물이 에탄올 추출물 보다 수율이 높았다. 박주가리 잎과 줄기의 열수 및 에탄올 추출물의 수율은 박주가리 잎의 열수 및 에탄올 추출물이 줄기 열수 및 에탄올 추출물에 비해 높았고, 박주가리 잎과 줄기 열수 추출물이 에탄올 추출물보다 수율이 높았다.

박주가리 잎과 줄기의 열수 및 $70 \%$ 에탄올추출물의 총 폴리페놀 함량은 박주가리 잎의 열수 추출물인 $\mathrm{ALWE}$ 에서 $66.50 \mathrm{mg} / \mathrm{g}$, 박주가리 줄기의 열수 추출물인 ASWE에서 $41.87 \mathrm{mg} / \mathrm{g}$, 박주가리 잎의 에탄올 추출물인 ALEE에서 $86.96 \mathrm{mg} / \mathrm{g}$, 박주가리 줄기의 에탄올 추출물인 $\mathrm{ASEE}$ 에서 $45.02 \mathrm{mg} / \mathrm{g}$ 으로 박주가리 잎의 열수 및 에탄올 추출물은 줄기 추출물보다 폴리페놀 함량이 높았으며, 박주가리 잎 의 에탄올 추출물은 열수 추출물에 비해 폴리페놀 함량이 높았다.
박주가리 잎과 줄기의 열수 및 $70 \%$ 에탄올추출물의 플 라보노이드 함량 측정 결과 박주가리 잎과 줄기의 열수 추출물은 각각 $40.25,15.88 \mathrm{mg} / \mathrm{g}$ 으로 박주가리 잎의 열수 추출물이 줄기 열수 추출물에 비해 플라보노이드 함량이 높았으며, 박주가리 잎과 줄기의 에탄올 추출물의 플라보 노이드 함량은 각각 $60.73,19.38 \mathrm{mg} / \mathrm{g}$ 으로 박주가리 잎의 에탄올 추출물이 줄기 에탄올 추출물에 비해 높았다. 또한 총 플라보노이드 함량은 박주가리 잎의 에탄올 추출물에서 가장 높았고, 박주가리 잎 열수 추출물, 박주가리 줄기 에탄 올 추출물, 줄기 열수 추출물 순이었다.

일부 약용식물 추출물에 함유된 총 폴리페놀 함량을 측 정한 Moon 등(33)이 애엽, 측백 등에 $4.41 ~ 8.55 \mathrm{mg} / \mathrm{g}$ 의 폴리 페놀이 함유되었다는 결과와 비교하면 박주가리 잎과 줄기 추출물의 함유량이 훨씬 높았다. 또한 일부 산채류의 에탄 올 추출물의 플라보노이드 함량을 분석한 Lee 등(34)의 결 과에서는 섬고사리 $16.75 \mathrm{mg} / \mathrm{g}$, 물엉겅퀴 $13.30 \mathrm{mg} / \mathrm{g}$ 과 비 교하면 박주가리 잎과 줄기 추출물에 함유된 플라보노이드 가 많이 함유된 것으로 분석되었다.

\section{전자공여능}

박주가리 잎과 줄기의 열수 및 $70 \%$ 에탄올 추출물의 항산화 활성 정도를 측정하고자 농도별 1,1-diphenyl-2-picryl hydrazyl(DPPH)에 대한 전자공여능을 측정한 결과는 Table 2 와 같으며, 대조구로서는 천연 항산화제인 ascorbic acid를 사용하였다. 박주가리 잎과 줄기의 열수 및 에탄올 추출물 의 전자공여능은 농도가 증가함에 따라 전자공여능은 증가 하였다. 추출물 농도 $62.5 \mu \mathrm{g} / \mathrm{mL}$ 의 농도에서는 박주가리 잎의 열수 추출물 $\mathrm{ALWE}$ 에서 $36.20 \%$ 로 다른 추출물에 비해 전자공여능은 다소 높았고, 125 500 $\mu \mathrm{g} / \mathrm{mL}$ 의 농도에 서는 박주가리 잎의 에탄올 추출물 $\mathrm{ALEE}$ 에서 전자공여능 이 높았으며, $1,000 \mu \mathrm{g} / \mathrm{mL}$ 의 농도에서는 박주가리 잎의 열 수 추출물 ALWE에서 68.19\%로 높았다. 대조구인 ascorbic

Table 2. Electron donating ability in the extracts of Metaplexis japonica Makino from leaf and stem

\begin{tabular}{cccccc}
\hline \multirow{2}{*}{ Samples $^{1)}$} & \multicolumn{5}{c}{ Electron donating ability (\%) } \\
\cline { 2 - 6 } & $62.5 \mu \mathrm{g} / \mathrm{mL}$ & $125 \mu \mathrm{g} / \mathrm{mL}$ & $250 \mu \mathrm{g} / \mathrm{mL}$ & $500 \mu \mathrm{g} / \mathrm{mL}$ & $1,000 \mu \mathrm{g} / \mathrm{mL}$ \\
\hline ALWE & $36.20 \pm 0.34^{\mathrm{b} 3)}$ & $36.26 \pm 0.33^{\mathrm{b}}$ & $37.12 \pm 0.41^{\mathrm{c}}$ & $40.96 \pm 0.25^{\mathrm{c}}$ & $68.19 \pm 0.66^{\mathrm{b}}$ \\
ASWE & $33.03 \pm 1.39^{\mathrm{c}}$ & $33.09 \pm 0.90^{\mathrm{c}}$ & $33.27 \pm 0.68^{\mathrm{e}}$ & $34.62 \pm 0.59^{\mathrm{e}}$ & $37.00 \pm 0.75^{\mathrm{d}}$ \\
ALEE & $34.25 \pm 1.30^{\mathrm{bc}}$ & $36.51 \pm 1.27^{\mathrm{b}}$ & $40.17 \pm 0.58^{\mathrm{b}}$ & $46.15 \pm 0.43^{\mathrm{b}}$ & $50.79 \pm 2.16^{\mathrm{c}}$ \\
ASEE & $34.25 \pm 1.02^{\mathrm{bc}}$ & $34.37 \pm 0.25^{\mathrm{c}}$ & $34.62 \pm 0.57^{\mathrm{d}}$ & $36.08 \pm 0.16^{\mathrm{d}}$ & $39.62 \pm 1.09^{\mathrm{d}}$ \\
AsA $^{2)}$ & $71.67 \pm 0.50^{\mathrm{a}}$ & $74.66 \pm 0.84^{\mathrm{a}}$ & $75.21 \pm 0.25^{\mathrm{a}}$ & $75.46 \pm 0.49^{\mathrm{a}}$ & $77.72 \pm 1.39^{\mathrm{a}}$ \\
\hline
\end{tabular}

${ }^{1)}$ ALWE, Aneilema japonica leaf water extract; ASWE, Aneilema japonica stem water extract; ALEE, Aneilema japonica leaf ethanol extract; ASEE, Aneilema japonica stem ethanol extract.

${ }^{2)}$ AsA, ascorbic acid.

${ }^{3)}$ All value are expressed as mean \pm SD of triplicate Determinations. Different superscripts within the column are significantly different at $p<0.05$ by Duncan's multiple range test. 
acid의 전자공여능이 농도에 따라 $71.67 \sim 77.72 \%$ 의 전자공 여능을 보였고, 박주가리 잎의 열수 추출물 ALWE는 36.20 68.19\%의 전자공여능을 보여 추출물의 농도가 증가 함에 따라 다른 추출물에 비해 높은 전자공여능을 보였다. 전자공여능은 free radical에 전자를 공여하여 지방질 산화 를 억제시키는 척도로 사용되고 있을 뿐만 아니라 인체 내에서 free radical에 의한 노화를 억제하는 작용의 척도로 사용된다. 이러한 radical을 환원시키거나 상쇄하는 능력이 크면 높은 항산화 활성 및 활성산소를 비롯한 다른 radical에 대한 소거 작용을 기대할 수 있다(35).

\section{SOD 유사활성능}

박주가리 잎과 줄기의 열수 및 $70 \%$ 에탄올 추출물의 SOD 유사활성능 측정결과는 Table 3과 같다. 박주가리 잎 과 줄기 열수 및 에탄올 추출물의 농도가 증가함에 따라 $\mathrm{SOD}$ 유사활성능은 증가함을 보였다. $62.5 \mu \mathrm{g} / \mathrm{mL}$ 의 농도에 서는 박주가리 잎의 에탄올 추출물 ALEE에서 $11.07 \%$ 의 SOD 유사활성능을 보였으며, 이는 대조구인 ascorbic acid 가 같은 농도에서 $10.48 \%$ 의 유사활성능을 보인 결과 보다 다소 높았으며, 그 다음으로 박주가리 잎의 열수 추출물인 ALWE는 8.60\%의 유사활성능을 보였다. 추출물 $500 \mu \mathrm{g} / \mathrm{mL}$ 의 농도 이상에서는 박주가리 잎의 열수 추출물 ALWE가 각각 $25.44,28.39 \%$ 로 다른 추출물에 비해 높은 SOD유사활 성능을 보였으며, 다음으로는 박주가리 잎의 에탄올 추출 물에서 높았다. 한국산 약용식물의 SOD 유사활성능을 측 정한 $\operatorname{Lim}$ 등(36)의 박하(15\%), 형개(11.60\%), 익모초

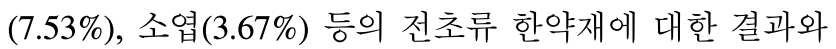
비교하면 박주가리 잎과 줄기 추출물의 SOD 유사활성능은 다소 높았다.

Table 3. SOD like activity in the extracts of Metaplexis japonica Makino from leaf and stem

\begin{tabular}{|c|c|c|c|c|}
\hline \multirow{2}{*}{ Samples } & \multicolumn{4}{|c|}{ SOD like activity (\%) } \\
\hline & $\mathrm{LL} \quad 125 \mu \mathrm{g} / \mathrm{mL}$ & $250 \mu \mathrm{g} / \mathrm{mL}$ & 5001 & \\
\hline ALWE & ab3) $12.60 \pm 2.85^{\text {abc }}$ & $17.20 \pm 1.11^{b}$ & $25.44 \pm 3.33^{b}$ & \\
\hline ASWE & $5.89 \pm 1.49^{c}$ & $7.89 \pm 4.08^{\mathrm{c}}$ & $11.07 \pm 3.48^{\mathrm{c}}$ & \\
\hline ALEE & $11.07 \pm 2.69^{\mathrm{a}} \quad 14.96 \pm 1.62^{\mathrm{ab}}$ & $17.79 \pm 1.46^{b}$ & $22.97 \pm 2.19^{b}$ & \\
\hline ASEE & $7.77 \pm 6.02^{\mathrm{bc}}$ & $5.54 \pm 2.22^{\mathrm{c}}$ & $12.96 \pm 1.85^{\mathrm{c}}$ & $13.31 \pm 1.49^{\mathrm{e}}$ \\
\hline $\mathrm{AsA}^{2)}$ & $10.48 \pm 6.96^{\mathrm{a}} \quad 16.25 \pm 3.11^{\mathrm{a}}$ & $29.92 \pm 0.91^{\mathrm{a}}$ & $56.65 \pm 1.02^{\mathrm{a}}$ & $77.15 \pm 1.43^{\mathrm{a}}$ \\
\hline \multicolumn{5}{|c|}{$\begin{array}{l}\text { 1)ALWE, Aneilema japonica leaf water extract; ASWE, Aneilema japonica stem water } \\
\text { extract; ALEE, Aneilema japonica leaf ethanol extract; ASEE, Aneilema japonica } \\
\text { stem ethanol extract. } \\
\text { ssa, ascorbic acid. } \\
\text { (All value are expressed as mean } \pm \text { SD of triplicate Determinations. Different superscripts } \\
\text { within the column are significantly different at } p<0.05 \text { by Duncan's multiple range } \\
\text { test. }\end{array}$} \\
\hline
\end{tabular}

\section{아질산염 소거능}

박주가리 잎과 줄기의 열수 및 $70 \%$ 에탄올 추출물의
아질산염 소거능을 $\mathrm{pH} 1.2$ 와 $\mathrm{pH} 3.0$ 에서 측정한 결과는 Table 4, 5와 같다.

Table 4. Nitrite scavenging ability in the extracts of Metaplexis japonica Makino from leaf and stem in $\mathrm{pH} 1.2$

\begin{tabular}{llllll}
\hline \multirow{2}{*}{ Sample $^{1)}$} & \multicolumn{5}{c}{ Nitrite scavenging ability (\%) } \\
\cline { 2 - 6 } & $62.5 \mu \mathrm{g} / \mathrm{mL}$ & $125 \mu \mathrm{g} / \mathrm{mL}$ & $250 \mu \mathrm{g} / \mathrm{mL}$ & $500 \mu \mathrm{g} / \mathrm{mL}$ & $1,000 \mu \mathrm{g} / \mathrm{mL}$ \\
\hline ALWE & $54.47 \pm 0.24^{\mathrm{b} 3)}$ & $54.51 \pm 0.23^{\mathrm{b}}$ & $54.68 \pm 0.65^{\mathrm{c}}$ & $57.86 \pm 0.18^{\mathrm{c}}$ & $77.30 \pm 0.47^{\mathrm{b}}$ \\
ASWE & $52.33 \pm 0.99^{\mathrm{c}}$ & $53.03 \pm 0.44^{\mathrm{c}}$ & $54.55 \pm 0.71^{\mathrm{c}}$ & $55.95 \pm 0.42^{\mathrm{c}}$ & $56.60 \pm 0.65^{\mathrm{c}}$ \\
ALEE & $53.07 \pm 0.93^{\mathrm{bc}}$ & $54.68 \pm 0.91^{\mathrm{b}}$ & $57.30 \pm 0.41^{\mathrm{b}}$ & $61.57 \pm 0.31^{\mathrm{b}}$ & $64.88 \pm 1.54^{\mathrm{c}}$ \\
ASEE & $18.17 \pm 0.71^{\mathrm{d}}$ & $19.22 \pm 0.41^{\mathrm{d}}$ & $22.57 \pm 0.41^{\mathrm{d}}$ & $29.54 \pm 2.70^{\mathrm{d}}$ & $45.14 \pm 9.28^{\mathrm{d}}$ \\
AsA $^{2)}$ & $93.20 \pm 0.12^{\mathrm{a}}$ & $93.33 \pm 0.00^{\mathrm{a}}$ & $99.17 \pm 0.59^{\mathrm{a}}$ & $100.70 \pm 0.07^{\mathrm{a}}$ & $100.05 \pm 0.00^{\mathrm{a}}$ \\
\hline
\end{tabular}

${ }^{1)}$ ALWE, Aneilema japonica leaf water extract; ASWE, Aneilema japonica stem water extract; ALEE, Aneilema japonica leaf ethanol extract; ASEE, Aneilema japonica stem ethanol extract.

${ }^{2)}$ AsA, ascorbic acid.

${ }^{3)}$ All value are expressed as mean \pm SD of triplicate Determinations. Different superscripts within the column are significantly different at $p<0.05$ by Duncan's multiple range test.

박주가리 잎과 줄기의 열수 및 에탄올 추출물의 아질산 염 소거능을 $\mathrm{pH} 1.2$ 에서 측정한 결과는 Table 4 와 같다. 박주가리 잎과 줄기의 열수 및 에탄올 추출물의 농도가 증가함에 따라 아질산염 소거능은 증가함을 보였다. 박주 가리 추출물 $62.5 \mathrm{\mu g} / \mathrm{mL}$ 농도에서는 박주가리 잎 열수 추출 물인 ALWE가 $54.47 \%$, 박주가리 잎 에탄올 추출물 ALEE 은 53.07\%, 박주가리 줄기 열수 추출물 ASWE는 52.33\%, 박주가리 줄기 에탄올 추출물 $\mathrm{ASEE}$ 는 $18.17 \%$ 순으로 아질 산염 소거능을 보였고, 박주가리 잎 열수 추출물인 ALWE 에서 높은 아질산염 소거능을 보였다. 박주가리 추출물 $1,000 \mathrm{\mu g} / \mathrm{mL}$ 농도에서는 박주가리 잎 열수 추출물인 ALWE 가 $77.30 \%$, 박주가리 잎 에탄올 추출물 $\mathrm{ALEE}$ 은 $64.88 \%$, 박주가리 줄기 열수 추출물 ASWE는 $56.60 \%$, 박주가리 줄 기 에탄올 추출물 ASEE는 $45.14 \%$ 순으로 아질산염 소거능 을 보였고, 박주가리 잎 열수 추출물인 ALWE에서 높은 아질산염 소거능을 보였다.

박주가리 잎과 줄기의 열수 및 에탄올 추출물의 아질산 염 소거능을 $\mathrm{pH} 3.0$ 에서 측정한 결과는 Table 5와 같다. 박주가리 잎과 줄기의 열수 및 에탄올 추출물의 농도가 증가함에 따라 $\mathrm{pH} 1.2$ 에서와 같이 아질산염 소거능은 증가 함을 보였다. 박주가리 추출물 $62.5 \mathrm{\mu g} / \mathrm{mL}$ 농도에서는 박주 가리 줄기 열수 추출물 ASWE는 5.72\%, 박주가리 잎 열수 추출물인 $\mathrm{ALWE}$ 가 $4.90 \%$, 박주가리 잎 에탄올 추출물 $\mathrm{ALEE}$ 은 $4.53 \%$, 박주가리 줄기 에탄올 추출물 ASEE는 $0.11 \%$ 순으로 아질산염 소거능을 보였고, 박주가리 줄기 열수 추출물인 ASWE에서 높은 아질산염 소거능을 보였다. 박주가리 추출물 $1,000 \mu \mathrm{gg} / \mathrm{mL}$ 농도에서는 박주가리 잎 열 수 추출물인 ALWE가 $17.41 \%$, 박주가리 잎 에탄올 추출물 ALEE은 $16.41 \%$, 박주가리 줄기 열수 추출물 ASWE는 
Table 5. Nitrite scavenging ability in the extracts of Metaplexis japonica Makino from leaf and stem in $\mathrm{pH} 3.0$

\begin{tabular}{|c|c|c|c|c|c|}
\hline \multirow{2}{*}{ Sample ${ }^{1)}$} & \multicolumn{5}{|c|}{ Nitrite scavenging ability (\%) } \\
\hline & $62.5 \mu \mathrm{g} / \mathrm{mL}$ & $125 \mu \mathrm{g} / \mathrm{mL}$ & $250 \mu \mathrm{g} / \mathrm{mL}$ & $500 \mu \mathrm{g} / \mathrm{mL}$ & $\mathrm{g} / \mathrm{mL}$ \\
\hline ALWE & $4.90 \pm 0.98^{\mathrm{b} 3)}$ & $7.28 \pm 0.15^{\mathrm{bc}}$ & $9.47 \pm 0.36^{b}$ & $11.43 \pm 0.81^{b}$ & $17.41 \pm 1.74^{b}$ \\
\hline ASWE & $5.72 \pm 2.12^{\mathrm{b}}$ & $7.83 \pm 0.30^{b}$ & $10.73 \pm 0.30^{b}$ & $11.28 \pm 0.75^{b}$ & $13.59 \pm 0.35^{c}$ \\
\hline ALEE & $4.53 \pm 0.64^{b}$ & $6.38 \pm 0.55^{\mathrm{c}}$ & $9.50 \pm 0.29^{\mathrm{b}}$ & $12.21 \pm 0.40^{b}$ & $16.41 \pm 0.51^{b}$ \\
\hline ASEE & $0.11 \pm 0.10^{c}$ & $4.31 \pm 0.77^{\mathrm{d}}$ & $7.39 \pm 0.41^{\mathrm{c}}$ & $10.02 \pm 0.60^{b}$ & $13.40 \pm 2.31^{\mathrm{c}}$ \\
\hline $\mathrm{AsA}^{2)}$ & $12.14 \pm 0.53^{\mathrm{a}}$ & $14.85 \pm 0.66^{\mathrm{a}}$ & $40.09 \pm 1.94^{\mathrm{a}}$ & $68.34 \pm 3.41^{\mathrm{a}}$ & $86.23 \pm 0.40^{\mathrm{a}}$ \\
\hline \multicolumn{6}{|c|}{$\begin{array}{l}\text { ALWE, Aneilema japonica leaf water extract; ASWE, Aneilema japonica stem water } \\
\text { extract; ALEE, Aneilema japonica leaf ethanol extract; ASEE, Aneilema japonica } \\
\text { stem ethanol extract. } \\
\text { (1) AsA, ascorbic acid. } \\
\text { All value are expressed as mean } \pm \text { SD of triplicate Determinations. Different superscripts } \\
\text { within the column are significantly different at } p<0.05 \text { by Duncan's multiple range } \\
\text { test. }\end{array}$} \\
\hline
\end{tabular}

$13.59 \%$, 박주가리 줄기 에탄올 추출물 ASEE는 $13.40 \%$ 순 으로 아질산염 소거능을 보였고, 박주가리 잎 열수 추출물 인 ALWE에서 다른 추출물에 비해 다소 높은 아질산염 소거능을 보였다. 이러한 결과는 아질산염소거능이 $\mathrm{pH}$ 에 매우 의존적이며 $\mathrm{pH}$ 가 높을수록 소거효과가 감소된다는 Kytopoulos(37)의 결과와도 일치하였다.

Takashi 등(38)은 폴리페놀 화합물이 아질산염을 효과적 으로 분해하여 nitrosamine 생성을 효과적으로 억제한다고 하였다. 이상의 결과에서 박주가리 잎 열수 추출물의 경우 $1,000 \mathrm{\mu g} / \mathrm{mL}$ 농도에서 $70 \%$ 이상의 아질산염 소거활성을 보이므로 육제품이나 단백질이 다량 함유된 가공식품의 제조 시 아질산염 소거 효과를 가진 천연 첨가물로서의 이용 가능성이 있다고 생각된다.

\section{환원력}

박주가리 잎과 줄기의 열수 및 $70 \%$ 에탄올 추출물의 항산화 활성 정도를 측정하고자 농도별 환원력을 측정하였

Table 6. Reducing power in the extracts of Metaplexis japonica Makino from leaf and stem

\begin{tabular}{|c|c|c|c|c|c|}
\hline \multirow{2}{*}{ Samples ${ }^{1)}$} & \multicolumn{5}{|c|}{ Reducing power (Absorbance 700nm) } \\
\hline & & & & $500 \mu \mathrm{g} / \mathrm{mL}$ & \\
\hline ALWE & & $0.12 \pm 0.00^{\mathrm{b}}$ & & $0.23 \pm 0.00^{b}$ & \\
\hline ASWE & & & & & \\
\hline ALEE & $0.09 \pm 0$ & $0.11 \pm 0.01^{\mathrm{b}}$ & $0.13 \pm 0.00^{\mathrm{c}}$ & $0.21 \pm 0.00^{\mathrm{c}}$ & $0.40 \pm 0.01^{\mathrm{c}}$ \\
\hline ASEE & $0.05 \pm 0.00^{\mathrm{d}}$ & $0.09 \pm 0.00^{\mathrm{c}}$ & $0.12 \pm 0.01^{\mathrm{c}}$ & $0.17 \pm 0.00^{\mathrm{e}}$ & \\
\hline $\mathrm{BHT}^{2)}$ & $0.33 \pm 0.00^{\mathrm{a}}$ & $0.55 \pm 0.01^{\mathrm{a}}$ & $0.68 \pm 0.02^{\mathrm{a}}$ & $0.93 \pm 0.01^{\mathrm{a}}$ & \\
\hline \multicolumn{6}{|c|}{$\begin{array}{l}\text { 11) ALWE, Aneilema japonica leaf water extract; ASWE, Aneilema japonica stem water } \\
\text { extract; ALEE, Aneilema japonica leaf ethanol extract; ASEE, Aneilema japonica } \\
\text { stem ethanol extract. }\end{array}$} \\
\hline
\end{tabular}

으며, 측정 결과는 Table 6 과 같으며, 대조구는 BHT를 사용 하였다. 박주가리 잎과 줄기 열수 및 에탄올 추출물의 농도 가 증가할수록 환원력은 증가함을 보였다. 추출물 농도 $62.5 \mu \mathrm{g} / \mathrm{mL}$ 의 농도에서는 박주가리 줄기 에탄올 추출물 $\mathrm{ALEE}$ 에서 0.09 로 다른 추출물에 비해 다소 높은 환원력을 보였고, 그 다음으로 박주가리 잎 열수 추출물 ALWE에서 0.07 , 박주가리 줄기 열수 추출물 및 박주가리 줄기 에탄올 추출물이 각각 $0.05,0.05$ 의 순으로 환원력을 보였다. 박주 가리 추출물 $1,000 \mu \mathrm{g} / \mathrm{mL}$ 의 농도에서는 박주가리 잎 열수 추출물 ALWE가 0.44로 환원력이 높았으며, 다음으로는 박주가리 잎 에탄올 추출물 $\mathrm{ALEE}$ 에서 0.40 , 박주가리 줄기 열수 추출물 ASWE에서 0.37, 박주가리 줄기 에탄올 추출물 $\mathrm{ASEE}$ 에서 0.33 순으로 환원력을 보였다.

\section{Tyrosinase 저해 활성}

박주가리 잎과 줄기의 열수 및 $70 \%$ 에탄올 추출물의 tyrosinase 저해활성을 측정한 결과는 Table 7과 같다. 박주 가리 추출물의 농도 $62.5 \mu \mathrm{g} / \mathrm{mL}$ 의 농도에서는 박주가리 줄기 에탄올추출물인 $\mathrm{ASEE}$ 에서 $13.81 \%$ 로 다른 추출물에 비해 다소 높은 tyrosinase 저해활성을 보였으며, 그 다음으 로는 박주가리 잎의 열수 추출물 ALWE에서 $12.71 \%$ 의 저 해활성을 보였다. 박주가리 추출물 농도 $62.5 ~ 500 \mu \mathrm{g} / \mathrm{mL}$ 의 농도에서는 다른 추출물에 비해 박주가리 줄기 에탄올 추출 물 ASEE에서 다소 높은 저해활성을 보였으며, $1,000 \mu \mathrm{g} / \mathrm{mL}$ 의 농도에서는 박주가리 잎의 에탄올 추출물 ALEE에서 $57.04 \%$ 로 높은 저해활성을 보였다. 그 다음으로는 박주가 리 줄기 에탄올 추출물 ASEE 44.67\%, 박주가리 잎의 열수 추출물 $\mathrm{ALWE}$ 에서 $40.21 \%$, 박주가리 줄기 열수 추출물 $\mathrm{ASWE}$ 에서 $27.56 \%$ 순으로 나타났다. 그리고 박주가리 잎 과 줄기 열수 및 에탄올 추출물의 농도가 증가할수록 tyrosinase 저해활성이 높았다.

Table 7. Inhibition effects on tyrosinase in the extracts of Metaplexis japonica Makino from leaf and stem

\begin{tabular}{cccccc}
\hline \multirow{2}{*}{ Samples $^{1)}$} & \multicolumn{5}{c}{ Tyrosinase inhibition (\%) } \\
\cline { 2 - 6 } & $62.5 \mu \mathrm{g} / \mathrm{mL}$ & $125 \mu \mathrm{g} / \mathrm{mL}$ & $250 \mu \mathrm{g} / \mathrm{mL}$ & $500 \mu \mathrm{g} / \mathrm{mL}$ & $1,000 \mu \mathrm{g} / \mathrm{mL}$ \\
\hline ALWE & $12.71 \pm 0.59^{\mathrm{b} 3)}$ & $17.87 \pm 3.51^{\mathrm{b}}$ & $29.07 \pm 4.06^{\mathrm{b}}$ & $32.65 \pm 1.23^{\mathrm{bc}}$ & $40.21 \pm 1.03^{\mathrm{c}}$ \\
ASWE & $9.90 \pm 0.92^{\mathrm{b}}$ & $11.34 \pm 2.13^{\mathrm{c}}$ & $15.95 \pm 1.74^{\mathrm{cd}}$ & $24.67 \pm 3.94^{\mathrm{c}}$ & $27.56 \pm 7.64^{\mathrm{d}}$ \\
ALEE & $4.47 \pm 0.91^{\mathrm{c}}$ & $11.55 \pm 2.93^{\mathrm{c}}$ & $12.85 \pm 2.93^{\mathrm{d}}$ & $32.99 \pm 4.88^{\mathrm{bc}}$ & $57.04 \pm 2.10^{\mathrm{b}}$ \\
ASEE & $13.81 \pm 0.92^{\mathrm{b}}$ & $18.35 \pm 1.69^{\mathrm{b}}$ & $20.82 \pm 2.54^{\mathrm{c}}$ & $37.25 \pm 7.93^{\mathrm{b}}$ & $44.67 \pm 4.64^{\mathrm{c}}$ \\
AsA $^{2)}$ & $53.33 \pm 4.36^{\mathrm{a}}$ & $73.68 \pm 3.78^{\mathrm{a}}$ & $74.98 \pm 5.42^{\mathrm{a}}$ & $89.42 \pm 2.10^{\mathrm{a}}$ & $100.00 \pm 0.00^{\mathrm{a}}$ \\
\hline
\end{tabular}

${ }^{11}$ ALWE, Aneilema japonica leaf water extract; ASWE, Aneilema japonica stem water extract; ALEE, Aneilema japonica leaf ethanol extract; ASEE, Aneilema japonica stem ethanol extract.

${ }^{2)}$ AsA, ascorbic acid.

${ }^{3)}$ All value are expressed as mean $\pm \mathrm{SD}$ of triplicate Determinations. Different superscripts within the column are significantly different at $p<0.05$ by Duncan's multiple range test. 


\section{요 약}

본 연구는 새로운 기능성 소재의 개발에 우선하여 박주 가리 잎과 줄기의 열수 및 $70 \%$ 에탄올 추출방법에 따라 각 추출물에 대한 항산화 활성을 측정함으로써 천연 항산화 제 개발에 필요한 기초자료를 얻고자 하였다. 박주가리 잎 과 줄기의 열수 및 에탄올 추출물의 수율 측정 결과 박주가 리 잎의 열수 추출물은 $6.89 \%$ 으로 다소 높았고, 총 폴리페 놀 함량 및 플라보노이드 함량은 박주가리 잎의 에탄올 추출물인 $\mathrm{ALEE}$ 에서 각각 $86.96,60.73 \mathrm{mg} / \mathrm{g}$ 으로 가장 높았 다. 전자공여능은 박주가리 잎의 열수 추출물 $\mathrm{ALWE}$ 는 추 출물 농도에 따라 36.20 68.19\%의 전자공여능을 보여 다른 추출물에 비해 높은 전자공여능을 보였다. SOD 유사활성 능은 추출물의 농도가 증가함에 따라 박주가리 추출물 $\mathrm{ALWE}, \mathrm{ALEE}$ 에서 다소 높았다. 아질산염 소거능 측정 결 과 $\mathrm{pH} 1.2$ 에서 3.0 에 비해 소거능은 높았으며, 박주가리 잎 열수 추출물인 $\mathrm{ALWE}$ 에서 높은 아질산염 소거능을 보였 다. 환원력 측정 결과 추출물 농도 $62.5 \mu \mathrm{g} / \mathrm{mL}$ 에서는 박주가 리 잎 에탄올 추출물 $\mathrm{ALEE}$ 에서 0.09로 다른 추출물에 비해 다소 높은 환원력을 보였고, 추출물 $1,000 \mu \mathrm{g} / \mathrm{mL}$ 의 농도에 서는 박주가리 잎 열수 추출물 ALWE가 0.44로 환원력이 높았다. Tyrosinase 저해활성 측정 결과에서는 $62.5 \mu \mathrm{g} / \mathrm{mL}$ 농도에서는 박주가리 줄기 에탄올추출물인 $\mathrm{ASEE}$ 에서 $13.81 \%$ 로 다소 높았으며, $1,000 \mu \mathrm{g} / \mathrm{mL}$ 의 농도에서는 박주 가리 잎의 에탄올 추출물 $\mathrm{ALEE}$ 에서 $57.04 \%$ 로 높은 저해활 성을 보였다. 그리고 박주가리 잎과 줄기 열수 및 에탄올 추출물의 농도가 증가할수록 tyrosinase 저해활성이 높았다.

\section{References}

1. MeCord JM (1987) Oxygen derived radicals : a link between repercussion injury and inflammation. Fed Proc, 46, 2402-2406

2. Imalay IA, Lim S (1989) DNA damage and oxygen radical toxicity. Science, 240, 1302-1309

3. Cho JS (1997) Food Material Science. Moon Woon Dang, Seoul, Korea, p 267

4. Lee HS (1997) Dietary fiber intake of Korea. J Korean Soc Food Sci Nutr, 25, 540-548

5. Choi BD (2010) Analysis of the contents and physiological activities of Calystegia japonica leaf extracts. Korean J Food Sci Technol, 42, 250-255

6. Vidlea LA, Fermandez V (1998) Biochemical aspects of cellular oxidative stress. Arch Biol Med Exp, 21, 85-92

7. Halliwell B, Aruoma OJ (1991) DNA damage by oxygen-derived species. FEBS Lett, 2811, 9-19
8. Jennings PE, Barnett AH (1988) New approaches to the pathogenesis and treatment of diabetic microangicpathy. Diabetic Med, 5, 111-117

9. Fridovich I (1989) Superoxide dismutase. An adaption to a paramagnetic gas. J Biol Chem, 264, 7761-7764

10. Branen AL (1991) Toxicological and biochemistry of butylated hydroxyanisole and butylated hydroxytoluene. J Am Oil Chem Soc, 52, 59-63

11. Barlow SM (1990) Toxicological aspects of antioxidants used as food additives. In: Food Antioxidant, Hudson BJF (Editor). Elsevier, Amsterdam, p 253-307

12. Eliott JG (1999) Application of antioxidant vitamins in foods and beverages. Food Tech, 53, 46-48

13. Yamamoto K, Niki E (1988) Proxidant effect of a -tocopherol. Biochem. Biophys Acta, 958, 19-23

14. Nam SH, Kang MY (2000) Screening of antioxidative activity of hot-water extracts from medicinal plants. J Korean Soc Agric Chem Biotecnol, 43, 141-147

15. Kim SM, Cho YS, Sung SK (2001) The antioxidant ability and nitrite scavenging ability of plant extracts. Korean J Food Sci Technol, 33, 626-632

16. Yang SA, Im NK, Lee IS (2007) Effects of methanolic extract from Salvia miltiorhiza Bunge on in vitro antihrombotic and antioxdiative activities. Korean J Food Sci Technol, 39, 83-87

17. Yoon GA (2006) Effect of garlic supplement and exercise on plasma lipid and antioxidative enzyme system in rats. Korean Food Nutr Sci, 39, 3-10

18. Han SH, Woo NY, Lee SD, Kang MH (2006) Antioxidative and antibacterial activities of endemic plants extracts in Korea. Korean J Medicinal Crop Sci, 14, 49-55

19. Kim HY, Park YK, Kim TS, Kang MH (2006) The effect of green vegetable drink supplementation on cellular DNA damage and antioxidant status of Korean smokers. Korean Food Nutr Sci, 39, 18-27

20. Branen AL (1975) Toxicology and biochemistry of butylated hydroxyanisole and butylated hydroxytoluene. J Am Oil Chem Soc, 52, 59-63

21. Jorge M, Ricardo DS, Jacques R, Vernonique C, Anni C, Michel M (1991) Procyanidin dimers and trimers from grape seeds. Phytochem, 30, 1259-1264

22. Lee SY, Kim JS, Kang SS (2012) Flavonol glycosides from the aerial parts of Metaplexis japonica. Kor $\mathrm{J}$ Pharmacogn, 43, 206-212

23. Kim MJ, Kim IJ, Choi SY, Han DH, Kim YH, Lim SC, Kim TJ, Nam SY, Song BH, Oh BU, Park CG (2014) 
Comparison of Cynanchum wilfordii, C. auriculatum, Metaplexis japonica and Polygonum multiflorum by morphological characters. Korean J Medicinal Cro Sci, 22, $113-120$

24. Singleton VL, Rossi A (1965) Colorimetry of total phenolics with phosphotungstic acid reagents. Am J Enol Viticult, 16, 144-158

25. Moreno VL, Isla MI, Sampietro AR, Vattuone MA (2000) Comparison of the free radical-scavenging activity of propolis from several regions of Argentina. J Ethnopharmacol, 71, 109-114

26. Blois ML (1958) Antioxidant determination by the use of a stable free radical. Nature, 181, 1199-1224

27. Marklund S, Marklund G (1974) Involvement of the superoxide anion radical in the autoxidation of pyrogallol and a convenient assay for superoxide dismutase. Eur J Biochem, 47, 469-474

28. Kato H, Lee IE, Chuyen NV, Kim SB, Hayase F (1987) Inhibitory of nitrosamine formation by nondilyzable melanoidins. Agric Biol Chem, 51, 1333-1338

29. Stirpe F, Corte ED (1969) The regulation of rat liver xanthine oxidase. J Biol Chem, 244, 3855-3861

30. Yagi A, Kanbara T, Morinobu N (1987) The effect of tyrosinase inhibition by aloe extract. Planta Medica, 53, 515-517

31. Wong JY, Chye FY (2009) Antioxidant properties of selected tropical wild edible mushrooms. J Food Comp Anal, 22, 269-277
32. Park WP (2014) Quality characteristics of noodles added with Houttuynia cordata Thunb powder. Korean J Food Preserv, 21, 34-39

33. Moon JS, Kim SJ, Park YM, Hwang JS, Kim EH, Park JW, Park IB, Kim SW, Kang SG, Park YK, Jung ST (2004) Activities of antioxidation and alcohol dehydrogenase inhibition of methanol extracts from some medicinal herbs. Korean J Food Preserv, 11, 201-206

34. Lee SO, Lee HJ, Yu MH, Im HG, Lee IS (2005) Total polyphenol contents and antioxidants activities of methanol extracts from vegetables produced in Ullung island. Korean J Food Sci Technol, 37, 233-240

35. Isono R. Yomokazu T, Esumi K (2005) Preparation of $\mathrm{Au} / \mathrm{TiO}_{2}$ nano composities and their catalytic activity for DPPH radical scavenging reaction. J Colloids Interf Sci, 288, 177-183

36. Lim JD, Yu CY, Kim MJ, Yun SJ, Lee SJ, Kim NY, Chung IM (2004) Comparison of SOD activity and phenolic compound contents in various Korean medicinal plants. Korean J Medicinal Crop Sci, 12, 191-202

37. Kytopoulos SA (1987) Ascorbic acid and formation of $\mathrm{N}$-nitroso compounds, possible role of ascorbic acid in cancer prevention. Am J Clin Nutr, 45, 1344-1350

38. Takashi Y, Yamamoto M, Tamura A (1978) Studies on the formation of nitrosamines. The effects of some polyphenols on nitrosation of diethylamine. J Food Hyg Soc, 19, 224-229 